\title{
Social business in multinational corporations: an analysis of marketing practices
}

\author{
Thiago José de Chaves ${ }^{1 A}$, Thelma Valéria Rocha ${ }^{B}$, \\ Jana Reuther', Renata Fernandes Galhanone ${ }^{\mathrm{B}}$ \\ AFaculdade Católica de Santa Catarina - FACASC, Florianópolis, SC, Brasil \\ ${ }^{B}$ Escola Superior de Propaganda e Marketing - ESPM/SP, São Paulo, SP, Brasil \\ ${ }^{\mathrm{C}}$ The University of Sidney, Sydney, Australia
}

ARTICLE DETAILS
Article history:
Received 19 March 2016
Accepted 21 April 2017
Available online in 30 April 2017
Double Blind Review System
Scientific Editor
Ilan Avrichir

Keywords:

Social Business

Multinational Corporations

Marketing Strategy

Low-Income Markets

\begin{abstract}
Social business (SB) as a category of organization that seeks to create longterm economic and social value for the majority of the people has attracted the attention of policy-makers, practitioners, and scholars. Some authors highlight the role that multinational corporations (MNCs) have in mitigating social and environmental problems by offering products and services to meet the demands of lower-income populations. Based on a discussion of social business and such initiatives inside MNCs, this article investigates how the Brazilian subsidiaries of two large MNCs (Coca-Cola and Danone) are conducting SB in a developing country. More specifically, we focused on how they are using their marketing know-how to achieve the desired results. The cases were chosen based on their global relevance and representativeness as SB ventures. Our study shows that these social initiatives are linked to the companies' corporate missions, values, and strategies, and that they aim to achieve social transformation in connection to their core business. Our goal is to contribute to both academic research and future initiatives in Brazil and in other developing countries.
\end{abstract}

(C) 2017 Internext | ESPM. All rights reserved.

\section{Introdution}

In response to current social and environmental challenges including social inequality and depletion of natural resources, the phenomenon of the social enterprise (SE) as a distinct category of organization has attracted the attention of policy-makers, practitioners, and scholars (Doherty et al., 2014). This type of enterprise may come in different forms, ranging from the private sector to the third sector model (Comini et al., 2012).

To promote a capitalist system that creates longterm economic and social value for the majority of the global community, the corporate world must go beyond the concept of philanthropy and seek business solutions in the field of economics (Chu,
2007; Prahalad, 2006; Prahalad \& Hart, 2002; Sachs, 2005). More mature initiatives based on privatesector social investments and corporate responsibility embrace a systemic, innovative, and multidimensional view of corporate sustainability (Fischer \& Comini, 2012).

Until recently, academic researchers focused on either civil society organizations and social movements or corporate responsibility in relation to social-environmental issues (Fischer \& Comini, 2012). Whereas early research was dominated by efforts to define the distinctive characteristics of social enterprises, new theories have more recently been proposed to explain their emergence and management (Doherty et al., 2014; Tracey et al., 2011), as reflected in the rising number of academic

\footnotetext{
${ }^{1}$ Author's contact: contatotchaves@gmail.com
} 
publications about SE (Cukier et al., 2011; Lepoutre et al., 2013).

Prahalad and Hart (2002) prompted a discussion on the important role that multinational companies (MNCs) might have in mitigating social and environmental problems. MNCs are no longer expected to perform only corporate social responsibility activities, which may be limited, and even ineffective, in helping improving the living standards of marginalized people. Instead, they should offer innovative products and services to meet types of demand that are different from what large corporations traditionally focused on (Spiess-Knafl et al., 2015).

Based on a discussion of social business (SB), this article aims to investigate how multinational corporations are undertaking social initiatives in a developing country, and more specifically, how they are using their marketing know-how to achieve results, based on Kotler's (2010) model. We seek to contribute to the literature on how to scale up social value in developing markets (Bocken et al., 2016) within the scope of multinational corporations (Spiess-Knafl et al., 2015).

We focused our research on the Brazilian subsidiaries of two MNCs (Coca-Cola and Danone); thanks to their impressive global reach, they are positioned as potential promoters of a more sustainable and inclusive kind of capitalism. Both corporations have been recognized for their advances by IRIS (Impact Reporting and Investment Standard), a standard created in 2009 by a group of investors to measure the social and environmental impact of social businesses (IRIS, 2009). Therefore, they serve as two representative instances of SB initiatives run by MNCs in a developing market. We aim to contribute both to academic research and to future initiatives in Brazil and in other developing countries.

Our study has shown that these multinational corporations are developing social initiatives that are linked to their corporate mission, values and strategies in order to achieve social transformation intrinsically connected to their core business. In both cases, the business models were developed inside the local subsidiary, according to theory (e.g., Hart, 2006; Porter \& Kramer, 2011; Sachs, 2005). Additionally, there is remarkable knowledge exchange between the companies and the targeted communities.
This article is structured as follows: first, we review the literature on social business, social entrepreneurship, and the role played by MNCs in creating social impact. Next, we detail the methodological procedures and describe the results of our research. Finally, we discuss the implications of these findings and the main limitations of the study, and we make recommendations for further research.

\section{Theoretical Background}

We start with an overview of social business in the international literature. Next, we discuss the role played by multinational corporations in trying to alleviate issues such as poverty, inequality, and social exclusion. Finally, we discuss these practices from the point of view of marketing and the marketing mix.

\subsection{Social Business and Social Entrepreneurship}

According to economic theory, market failures cause externalities and inefficiencies that are reflected in environmental and social problems. Market imperfections present opportunities for new entrepreneurial ventures to find solutions for them and to achieve economic gain in the process (Cohen \& Winn, 2007). Social entrepreneurs differ from traditional entrepreneurs by substituting profit maximization for the creation of shared value, social inclusion, and environmental awareness (Dees, 1998; Yunus, 2004).

Social entrepreneurship may be seen as a comprehensive term, as it refers to innovative activity with a social goal, whether in the private or third sector, or in hybrid organizations (Austin et al., 2006). The ideal type of social entrepreneurship weds a pure social mission (non-financial objectives) with a high degree of innovation in terms of introduction of new methods, services, or products to generate social change (Austin et al., 2006; Cukier et al., 2011; Rosolen et al., 2014). Innovation may be considered the most distinguishing trait of social entrepreneurship (Yunus et al., 2010).

As for Social Business (SB), there are two main theoretical approaches. The European perspective, born from the Social Economy tradition (associations and cooperatives), emphasizes actions by civil society organizations to carry out public duties with governmental support (Fischer \& Comini, 2012; Seelos \& Mair, 2005). The American perspective refers to social businesses as private-sector 
organizations that use a market-based logic to find viable solutions for social problems (Dees, 1998; Seelos \& Mair, 2005; Rosolen et al., 2014). Thus, the concept includes any entrepreneurial activity that encompasses social and/or environment impact as its primary objective, even if it is a business unit embedded in a traditional company (Comini et al., 2012). Economic value creation is often a by-product that allows the organization to achieve efficiency, sustainability, and self-sufficiency (Dees, 1998).

The three perspectives have in common the existence of organizations that aim to solve social problems using market mechanisms. Their differences lie in the perception of the most effective way to achieve this goal. Whereas the American perspective seeks shared value, in which private sector organizations use their strengths to create innovative, market-based solutions to address social problems, the European perspective emphasizes the role of civil society organizations (Comini et al., 2012).

Social businesses are hybrid organizations halfway between the two poles of for-profit and nonprofit organizations (Yunus et al., 2010; Rosolen et al., 2014; Moura et al., 2015; Doherty et al., 2014). They are similar to traditional businesses in aspects such as products, services, customers, markets, costs, and revenues, but they differ in their core business, which is to serve society and improve living standards for low-income populations. They are also distinct from non-government organizations (NGOs) in that they try to be self-sustainable by means of selling products and services rather than depending on donations and grants (Defourny \& Nyssens, 2010; Yunus et al., 2010).

Their principal aim is not to maximize profits for owners, investors or shareholders, but to maximize social impact and address the needs of the most vulnerable and marginalized members of society (Roy et al., 2015). Profits are to be reinvested in the business or in the beneficiary community in the form of price reductions, better services or greater accessibility (Yunus et al., 2010; Rosolen et al., 2014; Moura et al., 2015). They are required to be profitable in order to stay in business, but this is not their primary purpose (Roy et al., 2015).

To manage these tensions, Doherty et al. (2014) suggest using the social mission as a strategic direction to find the optimum conditions, in which the generation of commercial revenue can be linked successfully to the creation of social value. As in any business, social entrepreneurs must understand external environment needs to adapt internal factors through managerial means (Weerawardena \& Mort, 2006). Finally, for a social business to be effective, it must have a real-life impact and present quantifiable results (Seelos \& Mair, 2005).

In view of the complexity of SB organizations, suggested topics for further investigation include how to assess performance (Yunus et al., 2010) and which strategies to employ for scaling up social impact in developing markets (Bocken et al., 2016). Tensions inherent in the contrasting value systems of private, public, and non-profit organizations, as well as strategies for satisfying multiple goals, can serve as research themes for scholars interested in the dynamics of hybrid organizations (Doherty et al., 2014).

\subsection{Social Business and Multinational Corporations}

Social businesses encompass distinct organizational formats, from non-profit organizations to market initiatives within a large or multinational company, all of which try to alleviate problems of low-income segments (Comini et al., 2012; Moura et al., 2015).

A multinational corporation (MNC) is a large company that performs various business activities through a network of subsidiaries and affiliates located in multiple countries with active investments and international management. This capillarity allows MNCs to locate resources or technologies more efficiently and to carry out activities wherever it is most advantageous (Cavusgil et al., 2014). In Brazil, MNC subsidiaries played an important role in the country's initial industrialization process through investments, technology transfer, and export expansion (Doellinger \& Cavalcanti, 1975). MNCs endeavor to position their brands in foreign markets so that their image is preserved on a global basis. At the same time, they have to define which elements in their marketing programs must be standardized or adapted to local needs.

Authors who emphasize the role of MNCs in diminishing world poverty (e.g., Prahalad \& Hart, 2002; London \& Hart, 2011; Porter \& Kramer, 2011; Prahalad \& Hammond, 2002) posit that they have the skills, resources, and insights to propose solutions to create access to a better life on a worldwide basis. This proposition includes companies operating at the level of the so-called Base of the Pyramid (BoP), or lower-income populations, and not necessarily in 
areas such as health, education or housing (Prahalad, 2010). Prahalad and Hart (2002) defend this as an opportunity for big corporations to expand their business and, at the same time, to improve living conditions through products and services that are culturally sensitive, environmentally sustainable, and economically profitable. Authors such as Prahalad and Hart (2002), Porter and Kramer (2011), Seelos and Mair (2005), and Reficco (2010) are among the main proponents of social inclusion through consumption, especially in developing markets.

Social business inside large corporations has a distinct mission linked to the creation of social/shared value to customers (Dees, 1998; Porter \& Kramer, 2011). Porter and Kramer (2011) define shared value as a new way to develop products, serve markets, and build productive businesses for the benefit of both the company and society. Companies may use this as a market mechanism to offer benefits to underprivileged social categories, to improve living conditions for people at the base of the social pyramid, and to grant them access to essential services with better quality and lower prices (Hart, 2006; Sachs, 2005; Prahalad, 2006; Porter \& Kramer, 2011; Spiess-Knafl, et al., 2015).

Social business is different from corporate social responsibility (CSR) in that it involves a set of duly organized, planned actions (both internal and external), as well as a definition centered on the company's mission and core business - all targeting the needs of a certain community. Its performance is measured in terms of its return to stakeholders and society, consumer perceptions, and market expectations (Melo Neto \& Froes, 2002).

One example of SB inside an MNC is the Coletivo Coca-Cola project launched in 2009 by Coca-Cola Brasil. Its primary objective is twofold: to train lowincome youth as retail workers and/or entrepreneurs and to enhance product distribution and improve brand equity. Rather than corporate social responsibility, this is actually part of the company's marketing strategy. The company analyzes and evaluates both the social impact and efficiency in sales and distribution in a market that is difficult to reach (Comini et al., 2012).

For MNCs, building social businesses could be seen as a 'learning lab', offering an arena where managers can develop dynamic capabilities that could in turn be helpful to their main business (Yunus et al., 2010). Kiss et al. (2012) suggest studying the methods used by MNC subsidiaries in developing countries to learn how to overcome institutional limitations as well as economic, political, and cultural barriers.

On the other hand, Khanna and Palepu (2006) argue that local companies are much better adapted to operating under emerging market circumstances. Another contesting remark is that the for-profit approach to social business disregards the fact that the market structure of developing economies tends to favor supernormal profits. These serve economic elites rather than the poor, who have little access to a wide array of consumption/production alternatives (Agafonow \& Donaldson, 2015).

\subsection{Marketing Practices for Social Businesses}

According to Kotler (2010), facing social issues and promoting social change involve adapting traditional marketing elements to the characteristics of lowerincome populations. Segmentation, positioning, differentiation, and sales tactics, as well as the marketing mix (price, promotion, place, and productor the four Ps, as they are usually referred to), have to be designed while keeping the needs of this audience in mind, particularly in terms of reducing costs and generating social impact (Kotler, 2010). The marketing mix is essentially the best way to

\begin{tabular}{lll}
\hline No & $\begin{array}{l}\text { Elements of } \\
\text { Marketing }\end{array}$ & $\begin{array}{l}\text { Social Business Enterprise } \\
\text { Business Model }\end{array}$ \\
\hline 1 & Segmentation & Bottom of the Pyramid \\
2 & Targeting & $\begin{array}{l}\text { High Volume Communities } \\
\text { Social Business Enterprise }\end{array}$ \\
3 & Positioning & Social Entrepreneurship \\
4 & Differentiation & \\
5 & Marketing Mix & Products not Currently \\
& - Product & Accessible for \\
& & Low-Income Customers \\
& - Price & Affordable \\
& - Promotion & Word-of-Mouth \\
& - Place & Community Distribution \\
6 & Selling & Sales Force of Social \\
7 & & Entrepreneurs \\
8 & Brand & Iconic \\
9 & Procice & No-Frills \\
\hline
\end{tabular}

Fig. 1

Marketing model for social businesses

Source: Kotler (2010) 
implement an SB program. Figure 1 depicts the marketing model proposed by Kotler (2010).

The challenge is how to design and distribute products for developing markets to optimize economic viability, market penetration, and social benefits. In contrast with developed economies, developing countries lack many of the infrastructural and institutional features needed for markets to operate efficiently (Bocken et al., 2016). It is often difficult to find ways to make products and services available to the target group, which is often hard to trace and located in remote areas. The creation of a smart distribution system often needs new partnerships and a reduction in intermediaries (Spiess-Knafl et al., 2015).

Through marketing activities, companies are able to combine lower costs, good quality, sustainability, and profits (Hart, 2006; Prahalad, 2006). Hart (2006) defines four key points to succeed at Bottom of the Pyramid marketing: creating buying power through access to credit and income generation; shaping aspirations through consumer education and sustainable development; improving access via distribution and communication systems; and growing healthy markets through tailored product development and bottom-up innovation. Drawing from the Grameen Group experience, Yunus et al. (2010) posit that switching from a traditional to a social business model involves developing a value proposition that is focused on all targeted stakeholders, not solely on the customer.

Drawing on this review of the literature, we conducted a field research with the Brazilian subsidiaries of two global multinational corporations: Coca-Cola and Danone. Our research question may be summarized as: How do MNCs apply their marketing know-how and core competencies to social business in a developing market?

With this study we hope to add to similar initiatives (e.g., Comini et al., 2012; Yunus et al., 2010; Ghalib et al., 2009) and to the literature on how to scale up profit-generating social businesses (e.g., Bocken et al., 2016). Also, we would like to inform companies that may be interested in this kind of business venture.

\section{Methodology}

Our methodological approach was qualitative in nature and based on the richness of individual, subjective narratives in order to corroborate theoretical assumptions using a small sample (Yin, 2010; Lakatos \& Marconi, 2010). We conducted a dual case study with subsidiaries of two MNCs supported by documentary research and interviews with experts on SB to ensure an abundance of detail and information sources (Yin, 2010; Godoy, 1995).

We collected data from several sources: newspapers, magazines, and websites; corporate reports and videos; internal documents supplied by the sustainability and social business departments; video interviews with key staff members; and presentations and speeches on the social impact projects in seminars and conferences. These sources provided valuable information on the SB initiatives, their models and implementation, as well as company history and culture.

The field research was carried out with in-depth interviews using an unstructured script based on previously collected secondary data (Yin, 2010) and the literature review. The themes discussed were: (i) marketing tools used in SB (Kotler, 2010); (ii) marketing strategies aimed at sociocultural transformation (Prahalad \& Hammond, 2002; Prahalad, 2010); (iii) the marketing mix (four Ps) applied to SB (Kotler, 2010; Porter \& Kramer, 2011); (iv) the coordination of marketing activities (Hart, 2006); and ( $v$ ) the impact of marketing tools (SpiessKnafl et al., 2015; Comini et al., 2012; Kotler, 2010).

The case study comprised the Brazilian subsidiaries of two large foreign multinational corporations: Coca-Cola Brasil and Danone Brasil. The criteria used to select the cases were based on their global reach and internationalization process, their recognized expertise on SB and sustainability activities in Brazil and other countries (Comini et al., 2012; Barki et al., 2013), their representativeness as examples of MNCs driving social business, and their publication of annual reports on GRI (Global Reporting Initiative).

Before conducting the interviews with company executives, we interviewed three academic experts on SB and CSR, as well as the co-founder of Yunus Social Business Brazil. These interviews helped to clarify terms and models and define which multinational companies should be investigated.

At Coca-Cola Brasil, we interviewed two managers of social business units with significant experience with sustainability and SB initiatives, in addition to 
other areas such as planning, sales, operations, and finance. One has been working at Coca-Cola for 4 years and the other has worked there for 12 years.

The interviews were conducted between November 2013 and February 2014, either in person or via Skype, with each lasting approximately one hour.

We used content analysis to treat the collected data. Following Bardin (2007), the selected documents and the interview transcripts were systematically analyzed to yield a codification and interpretation of message content so that we could identify and organize themes and their indicators. Next, we accounted for frequencies and absences according to previously defined criteria (Bardin, 2007). We endeavored to find categories mentioned in the literature review, as well as "new" or specific categories that surfaced throughout the interview phase. Finally, as presented in the next section, the results were interpreted and compiled.

\section{Analysis and Results}

\subsection{Case 1 - Coca-Cola Brasil}

Coca-Cola Company has a global presence in over 200 countries with more than 400 brands. Since 2000, the company has increased its commitment to developing local communities, respecting diversity and cultural differences in order to cater to their specific needs (Coca-Cola, 2013). Since 1990, CocaCola Brasil has been involved in social, cultural, sports, and environmental projects. The present corporate mission includes sustainability as a commitment to people and the environment (CocaCola, 2013). In 2013, Coca-Cola Brasil invested R\$ 2.6 billion in social projects and announced plans to invest a total of R\$14 billion between 2012 and 2016 .

In 1999, Instituto Coca-Cola Brasil (ICCB) was created to consolidate corporate social investments and to help foster social change through projects focused on income generation, education, and environmental preservation (Coca-Cola, 2013). In 2009, ICCB created the Plataforma Coletivo program, whose goal is to increase self-esteem and income through education and training for potential entrepreneurs from poor communities (especially young people and women) in partnership with local entities (Coca-Cola, 2013). The company aims to use its capillarity, value chain, and scalability to collaborate with those communities in search for a better future. In the words of their Social Business Director, Claudia Lorenzo:

"This project was created to generate more opportunity and optimism for those populations. The goal is to transform people's lives and to expand this concept to other companies. If we can do that, so can other companies run similar projects and set an example."

Coletivo Coca-Cola's work revolves around seven areas: (1) design and development of products from recycled materials (Coletivo das Artes); (2) development of technical/behavioral competencies in retail for 60,000 low-income young people (Coletivo Varejo); (3) managerial, financial, and educational support for cooperatives of recyclables scavengers (Coletivo Reciclagem); (4) development of entrepreneurial skills for home-based business owners (Coletivo Empreendedorismo); (5) training young people to work in sports events (Coletivo Eventos); (6) training potential candidates on production and logistics skills to work at Coca-Cola production sites and other companies (Coletivo Logística e Produção); and (7) development of açaí berry harvesting communities in the Amazon region through shared-value, profit-generating projects, such as the recently launched mixed juice Del Valle Reserva (Açaí + Banana) (Coletivo Floresta).

The latter is a partnership between Coca-Cola Brasil and the government of the state of Amazonas. It focuses on improving living conditions for açaí berry pickers (açaí is a berry native to the Amazon region and is used as an ingredient in various products including beverages, foods, cosmetics, and supplements). Coletivo Floresta has three pillars: technical assistance; community empowerment; and access to a fair-trade value chain. Its innovative shared-value process promotes respect for local traditions, promotion of welfare, and preservation of biodiversity (Coca-Cola, 2013). Expected results include a direct impact on the living conditions of 600 harvesting families and an indirect impact on the lives of 1,200 members of other 50 communities (CocaCola, 2013). According to Marco Simões, vice president of Communication and Sustainability, "The innovation of Del Valle Reserva Açaí com Banana reflects our vision and our values. It is a product with nutritional benefits that is sustainable throughout its value chain" (Coca-Cola, 2013).

The Coletivo Coca-Cola platform is present in 150 communities all over Brazil. Between 2009 and 2013, 
it brought change to the lives of over 70,000 people through its seven social business models (Coca-Cola, 2013).

\subsubsection{Social Business at Coca-Cola Brasil}

This section summarizes the interview findings about the social business unit at Coca-Cola, their marketing practices, and the relationship with other corporate areas.

For the interviewees, Coca-Cola is in a unique position to help generate social impact on a large scale thanks to its size, strong brand, business expertise, and global presence. The motivation for creating a social business area within the company was the existence of serious social problems in Brazil.

First, it is clear to the interviewees that social business (SB) and corporate social responsibility (CSR) are distinct concepts. They stated:

"In the social business area we work with business models, while social responsibility deals with social projects."

"We build business models that generate social and economic impact. Social as it relates to a partnership with the community and economic in terms of return for the company. As compared to corporate social responsibility, SB has a closer relationship to the company's value chain. Because of this, it is more sustainable in the long run, and it is able to create social impact on a larger scale."

The SB area is connected to many other areas of the corporation (financial, marketing, planning) and utilizes their expertise in order to operate the Coletivo project. In the words of one of the respondents,

"Coletivo is not exclusive to the social business area. We lead and manage the project, but it is cocreated with other areas. We get contributions from finance, marketing, and other areas. This exchange needs to be nurtured."

From a marketing perspective, corporate and SB strategies are totally distinct. Traditionally, Coca-Cola Co. replicates global marketing and communication strategies defined by headquarters in most countries, with a few local adaptations. On the other hand, the Coletivo platform uses exclusively local marketing strategies. Even global marketing tools devised to reach lower-income consumers (such as lower-price offers) are not used.
Developing adequate marketing strategies (product, distribution, pricing) to reach consumers targeted by the Coletivo programs requires understanding them, their problems, and their environment. The marketing strategies are based on research, field trips, analyses by specialists, and evaluation of social demands, since Coletivo is a different business model. As stated by the interviewees:

"We need to understand the environment, the market, and this happens in the field. We need to listen to the communities, to their leaders, and involve other partners."

"And this is not really done by the marketing department (...), this is led by the SB department."

However, the SB area has not yet developed a specific marketing mix to design offers to these segments. Among the $4 \mathrm{Ps}$, the most used tool is promotion. Communications via TV and the internet, as well as at the point-of-sales, are used to attract more people to the educational programs developed by the Coletivo project. In addition to helping to spread the message among target communities, promotional activities also benefit the corporation:

"This improves the corporate image in general. So I would say that this is a marketing benefit that we are delivering to the Coca-Cola brand and company."

There is an exchange of expertise between the marketing department and the SB unit. They try to adapt traditional practices to find the best ways to reach segments and places that are difficult to access and to attract more people to participate in their educational programs. As an example:

"We use tracking tools to measure the impact we are making on the community, not only from a business point of view, but also from a social perspective."

In addition, knowledge of the bottom of the pyramid may help the marketing department solve, for example, distribution problems in remote places and improve Coca-Cola's competitive positioning in those markets through more adequate products formats and lower price points.

The results and knowledge generated by the Coletivo project in Brazil have become a structured Social Business model, which may be replicated in other countries and Brazilian regions, as long as it is adapted to local, specific needs. People from other 
subsidiaries in Latin America and Asia have already come to Brazil to learn about the operations. In the words of one of the executives:

"Based on social demand we develop a different model inside the company's value chain, according to our reality. In Mexico or elsewhere you have to adapt it to the local reality, but the concept we developed can be applied to any division of Coca-Cola. And it can work in other countries, too. For example, if the social issue is focused on small rural producers, the Coletivo Floresta technology may work. If the problem is unemployment, then the Coletivo aimed at getting people their first job can be adapted. For recycling matters there is a specific Coletivo."

\subsection{Case 2 - Danone Brasil}

Groupe Danone is one of the world's leading food companies, with a strong presence in over 120 countries with well-known brands of fresh dairy products, bottled water, biscuits, and cereal products. Danone has been present in Brazil since 1970 as a supplier of dairy products. Its headquarters are located in São Paulo, and there are several sales offices and distribution centers throughout the country (Danone, 2014).

According to Antoine Riboud, the former CEO of Groupe Danone, a company's role should be to harmonize economic and social performance. In 2006, Riboud formalized a partnership in Bangladesh between Danone and the Grameen Group, founded and led by Muhammad Yunus, the 2006 Nobel Peace Prize winner. Grameen Danone offers an affordable and easily available yoghurt developed to fulfill the nutritional needs of Bangladeshi children. The dairy product is produced locally and distributed door-todoor by Grameen ladies (Yunus et al., 2010). Riboud convinced shareholders that this enterprise could become an innovation laboratory for Danone (Época Negócios, 2007).

Grameen Danone is considered the world's first consciously designed multinational social business run as a for-profit organization (Yunus et al., 2010). The success of this joint venture has led Danone to invest in new business models, both to cope with globalization pressures and to meet the needs of those who have been so far neglected by the capitalist system. The group has created an investment fund (Danone Communities) with the aim to maximize their social impact. According to Riboud:
"There are three billion people living on $€ 2$ a day. Why not create a business model to cater for this enormous low-income group? Not out of charity, but focusing on shared profits." (Danone, 2014)

In 2013, the fund had $€ 73$ million to finance SB projects involving nutrition and drinking water. Ten projects benefitting one million persons have already been set up in developing countries (Danone, 2014).

In 2009, the new, $€ 100$ million fund "Ecosysteme Danone" was launched to operate in places where the company already had a commercial presence. Its purpose is to manage SB projects in connection with the company's value chain. Every project should be run in partnership with local NGOs and be based on three pillars: locally supplied raw materials to improve the living conditions of rural families; recycling of packaging materials by scavenger cooperatives; and micro-distribution through small players. Therefore, thanks to co-creation and innovation, all the stakeholders benefit from agricultural development, local distribution channels, recycling, nutritional development, and socioeconomic development (Danone, 2014).

In addition to their positive social impact, both funds have positive benefits for Groupe Danone, such as a sustainable development model, higher consumer trust, respect for the environment and society, attraction of talented people in search of a company with strong culture and values, and a competitive differential (Danone, 2014).

In 2011, the Ecosysteme fund launched a project called Kiteiras in Brazil to foster entrepreneurship among women from low-income communities in the city of Salvador, Bahia (Danone, 2014). This city was chosen because it is located in the northeastern region of Brazil, one of the poorest in the country, with a female unemployment rate much higher than the country's average.

The idea is to train and equip women to sell yoghurt kits door-to-door. Through training and education on business management, sales skills, health, and nutrition, those women can be transformed from informal workers into microentrepreneurs with a steady income. The project is run in partnership with the NGO Aliança Empreendedora and a human resources firm in charge of recruitment and training (Danone, 2014).

According to one of the project leaders: 
"Working at the Project Kiteiras has been my most interesting professional experience. Besides helping Brazilians, Danone has grown, and I had the opportunity to change the lives of those women."

Another SB project is Novo Ciclo, which seeks to foster entrepreneurship and professionalism among recycling cooperatives. More recently, Danone Brasil has established a partnership with the international NGO CARE in order to develop professional capabilities among small dairy farms (Danone, 2014).

\subsubsection{Social Business at Danone Brasil}

The in-depth interviews with the executives have made clear that Danone's SB falls under the umbrella of sustainability. Every project has social, environmental, and institutional aspects. According to one of the respondents:

"The proposal [of Ecosysteme] was that the SB units develop projects related to the core business and value chain, with a positive social impact in a "win-win" situation. In our understanding, sustainability must be connected to our business. If we will make a long-term investment, it has to be in something that makes sense for our core business."

Again, both executives made a clear distinction between corporate philanthropy and SB. The company invests money but wants to ensure that there is a measurable social impact before spreading a project to other regions. In essence, social impact makes sense as long as it is linked to the company's core business (health and nutrition) and value chain while simultaneously promoting autonomy and development in the targeted communities.

The sustainability department usually involves other corporate areas in the projects to transfer traditional business knowledge to the SB initiatives. The needs and demands of the people involved in the social projects are communicated to the company in order to complement traditional market research. As the marketing executive stated:

"We are always analyzing what the Kiteiras are selling, where, how, how much, what kind of kits they sell; all this helps us (...) By running a project like that we are dealing with people, and anything that helps us to better understand consumers' relationship to yoghurt is of interest."
The marketing department usually contributes its support in measuring strategic results and understanding new consumer segments. Together, both departments are able to test ways to help the ladies develop their business even further. In the words of one of the respondents:

"We want to learn if we could offer kits with higher price points. We try to help the ladies sell more by, for example, adding giveaways to the kits. We are trying to develop better kits, to make this project more attractive to consumers."

Knowledge transfer occurs in both directions, as many sales and communication practices were initiated by the Kiteiras themselves, such as selling through Facebook and distributing business cards. The partner NGOs are also responsible for applying marketing strategies developed inside the company.

In terms of a specific marketing mix for the SB project, no product has been developed specially for consumers in the base of the pyramid yet. However, a new line with distinct packaging and price points is under analysis. Distribution is a key aspect, not only in terms of understanding the door-to-door selling process but also for expanding the project to other areas of Brazil.

From a marketing point of view, Danone's social business is a way to generate new projects, thanks to acquired knowledge on how to sell to low-income segments - which product mix and price points to define, how to distribute, how to do market research, etc. The Brazilian subsidiary has benefited not only in terms of higher sales and economic value, but also by acquiring knowledge about consumers and entrepreneurs at the base of the pyramid.

Best practices developed by other subsidiaries are exchanged and locally adapted, too, as stated by one of the executives:

"Danone Brasil used the Mexican experience as a benchmark for phase two of the Kiteiras project, which is being designed taking into account our reality here (...) We have brought to Brazil the experience of using carts to sell door-to-door (...) and the idea of setting micro-distribution centers in Salvador to improve logistics in distant areas. This idea has also been taken from the Mexico experience and it is quite interesting." 


\subsection{Comparative analysis of the cases}

The aim of the field research was to understand how marketing knowledge and tools might contribute to foster MNC social businesses in a developing country. The case study supports Hart's (2006) argument that marketing can help create a positive social impact.

According to Kotler (2010) and Prahalad (2008), neither company has developed a full business model
However, the Coletivo Floresta project has led to an increase in income by including small producers into Coca-Cola's value chain. The Kiteiras project has done the same by training female entrepreneurs from a very poor area. Therefore, we can certainly posit that in both cases the MNCs are helping to improve income levels by increasing economic activity and fostering sociocultural transformation in local communities.

\begin{tabular}{lll}
\hline Category & Coca-Cola & Danone \\
\hline Marketing practices in SB & Advertising the Coletivo projects through & Consumer research, promotional \\
& TV, internet, and points of sales to reach & giveaways, definition of product mix/kits, \\
& targeted communities. & and pricing analysis.
\end{tabular}

\begin{tabular}{ll}
\hline $\begin{array}{l}\text { Marketing and sociocultural knowledge } \\
\text { exchange }\end{array}$ & Research and analysis of social demands \\
& to generate shared value, as in the \\
& Coletivo Floresta project.
\end{tabular}

Marketing strategies defined by the company and locally implemented by the partner NGO. Knowledge acquired in the field feeds back the process inside the company.

\begin{tabular}{ll}
\hline Marketing know-how applied & How to reach remote areas, how to Knowledge about door-to-door selling. \\
& attract more people to the projects. Communication with end-consumers. \\
Locally developed marketing strategies. & Locally developed marketing strategies.
\end{tabular}

Marketing mix to local communities

\author{
Price: not specific for low-end consumers \\ Promotion: advertising programs to \\ attract more people Place: feedback for \\ future distribution solutions in remote \\ places Product: not specific for low-end \\ consumers
}

\begin{abstract}
Price: not specific for low-end consumers Promotion: mostly carried out by Kiteiras Place: opportunity to expand the program to other regions Product: kits with affordable prices; future product development for low-end consumers
\end{abstract}

Fig. 2

Comparison of marketing practices.

Source: Developed by the authors.

or a marketing mix to sell specifically to the bottom of the pyramid. The only $P$ currently used is promotion in the form of advertising on TV, the internet, and at points-of-sale to try to create a connection with the targeted audiences. Although neither has developed a distinctive, low-cost product to offer to the bottom of the pyramid, Danone is closer to this goal, having devised product kits that are more affordable to low-end consumers. Danone has fostered much greater interaction between the marketing and SB departments by collecting rich information on shopping practices, adequacy of average price points, product kits, research tools, and giveaway tactics. At Coca-Cola Brasil, on the other hand, this knowledge exchange process is not so clearly used by the marketing department.
Figure 2 shows a detailed comparison of both companies' marketing strategies and practices.

\section{Category Coca-Cola Danone}

Marketing practices in SB Advertising the Coletivo projects through $T V$, internet, and points of sales to reach targeted communities. Consumer research, promotional giveaways, definition of product $\mathrm{mix} /$ kits, and pricing analysis.

Marketing and sociocultural knowledge exchange Research and analysis of social demands to generate shared value, as in the Coletivo Floresta project. Marketing strategies defined by the company and locally implemented by the partner NGO. Knowledge acquired in the field feeds back the process inside the company. 
Marketing know-how applied How to reach remote areas, how to attract more people to the projects. Locally developed marketing strategies.

Knowledge about door-to-door selling. Communication with end-consumers. Locally developed marketing strategies.

Marketing mix to local communities Price: not specific for low-end consumers Promotion: advertising programs to attract more people Place: feedback for future distribution solutions in remote places Product: not specific for low-end consumers

Price: not specific for low-end consumers Promotion: mostly carried out by Kiteiras Place: opportunity to expand the program to other regions Product: kits with affordable prices; future product development for low-end consumers.

Marketing strategies are first designed in-house by the marketing department along with the sustainability or SB department. They are then implemented with help from NGOs with knowledge of local needs. Evidence points to the importance of strategic partnerships to expand the economic and social impact of marketing strategies as defined in the literature (e.g., Prahalad \& Hammond, 2002). However, both companies could make greater use of their marketing know-how to increase the positive impact of their social business initiatives and create shared value.

\subsection{The view of Social Business experts}

The interviews with SB experts revealed different perspectives than those of the people directly involved in the projects.

One of the academic experts considers Coletivo Coca-Cola a movement towards a business opportunity to cater to the needs of those at base of the pyramid, rather than an SB venture. In his words: "Coca-Cola with its Coletivo project is a typical case of Market Value Added, as defined by Hart." For him, the Danone project is a real SB case, as it follows Yunus's guidelines.

The co-founder of Yunus Social Business Brazil held the same position; he considers the Coca-Cola case as a shared-value example, focusing more on increasing sales than on solving a social problem. As he stated: "If the company does not forgo profits, then it becomes another business in their portfolio (...) The initiative will not have the same power." He also mentioned Danone among the good examples of companies who are developing SB around the world.

The second academic expert, who is also a member of the Social Enterprise Knowledge Network, considers both cases SB initiatives, although with a certain reservation regarding Coca-Cola. In his words: "From a more purist perspective, it is a bit exaggerated to consider Coletivo as an SB example, but, on the other hand, they are somehow making a contribution."

The last academic expert distinguishes between $\mathrm{SB}$ and businesses with a social impact. According to him, "Neither Danone, BR Foods, or Coca-Cola have social benefits as their core business. This is why I call [their initiatives] business with a social impact. On the other hand, multinationals have a different scale, a much higher impact. An initiative with this vision taken inside a multinational corporation has a much stronger impact than typical social businesses." He did mention Coca-Cola as a case for research.

Despite the divergent viewpoints shown by those experts, we believe that both Coca-Cola and Danone are in fact doing Social Business in Brazil. They may not be examples of "pure" SB initiatives, but they fall into the category of social business inside large corporations, whose mission is to create social/shared value to customers (Dees, 1998; Porter \& Kramer, 2011). Danone has helped changing the lives of poor women by developing their entrepreneurial skills and increasing their income. At the same time, the company has seen its market share grow in the low-end of the market. As for CocaCola, the expertise developed through the Coletivo platform has had an impact on 150 communities all over Brazil. Both cases are excellent examples of how to use market mechanisms to build productive businesses for the benefit of both the company and society (Porter \& Kramer, 2011).

Additionally, these projects involve not only the SB areas, but other departments as well, such as finance, marketing, and human resources. In some cases, the initiatives have become benchmarks for subsidiaries in other developing countries, and Danone has even become a global reference, with endorsement of Yunus's Grameen Group.

\section{Conclusions}

Through an analysis of two relevant cases in light of the extant literature, this study has shown that 
building a social business inside the scope of MNCs is both possible and desirable. Both cases show privatesector organizations that aim to address social problems using their strengths, as well as market mechanisms, to create innovative solutions, following the American perspective on SB (Comini et al., 2012).

Our field study has led to some relevant conclusions. First, their marketing practices follow the sociocultural transformation model, by which they try to empower local communities, either by inclusion in the organization's value chain or by distribution and sales of products. Second, the companies still have to go a long way to develop a specific marketing mix for their SB ventures. Third, creating a positive social impact may be facilitated by information exchange among target groups, partners, corporate areas, and subsidiaries. Finally, we stress the importance of strategic partnerships with social organizations and even other companies (Comini et al., 2012; Ghalib et al., 2009).

Social entrepreneurs do not need entirely different business models; they can draw from existing private sector and marketing knowledge to achieve and expand positive social impact. The goals of gaining financial sustainability and simultaneously creating social value, previously seen as incompatible, have become inseparable in SB (Comini et al., 2012). Moreover, co-creation has become extremely important as a strategy for being more locally relevant (Prahalad \& Hart, 2002).

Plataforma Coletivo shows how a big corporation can help with social inclusion by promoting education and income generation and, at the same time, benefitting from a better image, increased sales, and a stronger relationship with low-end communities (Barki et al., 2013). Project Kiteiras can be seen as a further development of Danone's commitment to understanding the needs of BoP groups to develop better social businesses in partnership with organizations created with a social end, such as Grameen (Barki et al., 2013). Other corporations have followed this path, such as the water company Veolia, Uniqlo, and the American food company McCain (The Guardian, 2017).

Finally, social businesses can learn from one another's best practices, which should be spread to other global partners and players to become a social force in the world. As posited by Yunus et al. (2010), $\mathrm{SB}$ can play prominent roles within MNCs, whether by affecting firm reputation or attracting prospective employees. Additionally, building social ventures can help develop managerial capabilities that could in turn be useful to a MNC's main business. According to Yunus (2008):

"Social business is not just a theoretical concept (...) Social businesses can become powerful players in the national and international economy, but we have a long way to go to achieve that goal. Existing companies of all shapes and sizes will want to launch their own social businesses. Some will choose to devote part of their annual profit to social business as part of their existing "social responsibility" mandates. Others will create social businesses as a way of exploring new markets while helping the less fortunate. They may create social businesses on their own, with the help of other companies, or in partnership with specialized social-business entrepreneurs."

We consider this article a step forward in enriching the literature on social business by bringing insights from initiatives developed in Brazil. However, our study is not free from limitations. Despite the extensive usage of case studies to validate theoretical concepts, their results cannot be generalized. Thus, our data cannot be considered as leading to definitive conclusions. First, the limited number of cases was due to difficulty in finding more MNC-sponsored social businesses in the Brazilian context, as many are still in the pre-project stage. Second, the concepts discussed are more related to MNCs or large organizations. Finally, the use of data collected mostly from the involved parties may slightly skew our results, although we tried to compensate for this by incorporating the outside view of field experts.

Further research is needed to study this type of business. Our suggestions include more studies on the role of marketing in SB and on how to develop products for the base of the pyramid. Another important question is defining strategic points from the perspective of different stakeholders. Finally, investigating the impact of SB models on brand value and credibility could be invaluable for this new and exciting knowledge field.

\section{References}

- Agafonow, A., \& Donaldson, C. (2015). The economic rationale behind the social business model: A research agenda. Social Business, 5(1), 5-16. 
- Austin, J., Stevenson, H., \& Wei-skillern, J. (2006). Social and commercial entrepreneurship: Same, different, or both? Entrepreneurship Theory and Practice, 30(1), 1.22.

- Bardin, L. (2007). Análise de conteúdo. 4 ed. Lisboa: Edições 70.

- Barki, E., Izzo, D., Torres, H., \& Aguiar, L. (2013). Negócios com impacto social no Brasil. São Paulo: Editora Peirópolis.

- Bocken, N.M.P., Fil, A. \& Prabhu, J. (2016). Scaling up social businesses in developing markets. Journal of Cleaner Production, Volume 139, 15 December. (pp. 295-308).

- Cavusgil, S. T., Knight, G., Riesenberger, J. R., Rammal, H. G., \& Rose, E. L.(2014). International business. Pearson Australia.

- Chu, M. (2007). Commercial returns at the base of the pyramid. Innovations: Technology, Governance, Globalization, v. 2, n. 1-2, p. 115-146.

- Coca-Cola (2013). <http://us.coca-cola.com/home/>. Access: Jan 15, 2013

- Cohen, B., \& Winn, M. I. (2007). Market imperfections, opportunity and sustainable entrepreneurship. Journal of Business Venturing, 22(1), 29-49.

- Comini, G., Barki, E., \& Aguiar, L. T. D. (2012). A threepronged approach to social business: a Brazilian multi-case analysis. Revista de Administração (São Paulo), 47(3), 385397.

- Cukier, W., Trenholm, S., Carl, D. \& Gekas, G. (2011).Social entrepreneurship: a content analysis. Journal of Strategic Innovation and Sustainability, 7, pp. 99-119.

- Danone Brasil (2014). <www.danone.com.br>. Access: Jan 10, 2015

- Dees, J. The meaning of social entrepreneurship. Boston: Harvard Business School, 1998

- Defourny, J., \& Nyssens, M. (2010). Conceptions of social enterprise and social entrepreneurship in Europe and the United States: Convergences and divergences. Journal of social entrepreneurship, 1(1), 32-53.

- Doellinger, C. V. \& Cavalcanti, L. (1975). Empresas multinacionais na indústria brasileira. Rio de Janeiro: IPEA/INPES.

- Doherty, B., Haugh, H., \& Lyon, F. (2014). Social enterprises as hybrid organizations: A review and research agenda. International Journal of Management Reviews, 16(4), 417436.

- Época Negócios (2007).O Estilo Danone. <http://epocanegocios.globo.com/Revista/Epocanegocios/ 0,,EDG77938-8374-5,00.html>. Access: Jan 15, 2014.

- Fischer, R. M., \& Comini, G. (2012). Sustainable development: from responsibility to entrepreneurship. Revista de Administração (São Paulo), 47(3), 363-369.

- Ghalib, A., Hossain, F., \& Arun, T. (2009). Social responsibility, business strategy and development: the case of GrameenDanone Foods Limited. Australasian Accounting Business \& Finance Journal, 3(4), 0_1.
- Godoy, A. S. (1995). Introdução à pesquisa qualitativa e suas possibilidades. Revista de Administração de Empresas, v. 35, n. 2, mar./abr.

- Hart, S. (2006).Capitalism at the crossroads: the unlimited business opportunities in solving the world's most difficult problems. New Jersey:

- IRIS, 2009 IRIS. Impact Reporting \& Investment Standards. 2009. <http://iris.thegiin.org/>. Access: May 10, 2014.

- Khanna,T. \& Palepu, K. (2006). Emerging giants: building world-class companies in developing countries. Harvard Business Review, Boston, v.84, n.10, p.60-69.

- Kiss, A. N., Danis, W. M., \& Cavusgil, S. T. (2012). International entrepreneurship research in emerging economies: A critical review and research agenda. Journal of Business Venturing, 27(2), 266-290.

- Kotler, P.(2010). Marketing 3.0. Rio de Janeiro: Editora Elsevier.

- Lakatos, E. M., \& Marconi, M. D. A. (2010). Fundamentos da metodologia científica. In Fundamentos da metodologia científica. Altas.

- Lepoutre, J., Justo, R., Terjesen, S. \& Bosma, N. (2013). Designing a global standardised methodology for measuring social entrepreneurship activity: the Global Entrepreneurship Monitor social entrepreneurship study. Small Business Economics, 40, pp. 693-714.

- London, T. \& Hart, S. (2011). Next generation business strategies for the base of the pyramid. New Jersey: Pearson Education.

- Melo Neto, F. P. \& Froes, C. (2002). Empreendedorismo social: a transição para a sociedade sustentável. Qualitymark Editora Ltda.

- Moura, A., Comini, G., \& Teodosio, A. D. S. D. S. (2015). The international growth of a social business: a case study. Revista de Administração de Empresas, 55(4), 444-460.

- Porter, M. E., \& Kramer, M. (2011). Creating shared value: Redefining capitalism and the role of the corporation in society. Harvard Business Review, Jan.

- Prahalad, C. K. (2006). The fortune at the bottom of the pyramid: eradicating poverty through profits. Wharton School Publishing.

- Prahalad, C. K., \& Hammond, A. (2002). Serving the world's poor, profitably. Harvard Business Review, 80(9), 48-59.

- Prahalad, C.K.\& Hart, S. (2002). The fortune at the bottom of the pyramid. Strategy + Business, New York, v.1, n.26, p.114.

- Reficco, E. L. (2010). Negocios inclusivos y responsabilidad social: un matrimonio complejo. Debates IESA, v. 15, n. 3.

- Rosolen, T., Tiscoski, G. P., \& Comini, G. M. (2014). Empreendedorismo social e negócios sociais: Um estudo bibliométrico da produção nacional e internacional. Revista Interdisciplinar de Gestão Social, 3(1).

- Roy, M.J., O'Connor, C.H., McHugh, N., Biosca, O., \& Donaldson, C. (2015). The New Merger: Combining Third 
Sector and Market-Based Approaches to Tackling Inequalities. Social Business, 5(1), 47-60.

- Sachs, J. (2005). The end of poverty: how we can make it happen in our lifetime. New York: Penguin.

- Seelos, C., \& Mair, J. (2005). Social entrepreneurship: Creating new business models to serve the poor. Business Horizons, 48(3), 241-246.

- Spiess-Knafl, W., Mast, C., \& Jansen, S. A. (2015). On the nature of social business model innovation. Social Business, 5(2), 113-130.

- The Guardian (2017), 'We Are All Entrepreneurs': Muhammad Yunus on changing the world, one microloan at a time. Available at: https://www.theguardian.com/sustainablebusiness/2017/mar/29/we-are-all-entrepreneursmuhammad-yunus-on-changing-the-world-one-microloanat-a-time
- Tracey, P., Phillips, N., \& Jarvis, O. (2011). Bridging institutional entrepreneurship and the creation of new organizational forms: A multilevel model. Organization science, 22(1), 60-80.

- Weerawardena a, J., \& Mort, G. S. (2006). Investigating social entrepreneurship: A multidimensional model. Journal of World Business, 41, 21-35.

- YIN, R. K. Estudo de caso: planejamento e métodos. Porto Alegre: Bookman, 2010.

- Yunus, M. (2004). Banker to the Poor: Micro-Lending and the battle against world poverty. Perseus Book.

- Yunus, M. (2008). Creating a World Without Poverty: Social Business and the future of Capitalism. Global Urban Development Magazine Volume 4, Issue 2 - November 2008.

- Yunus, M., Moingeon, B., \& Lehmann-Ortega, L. (2010). Building social business models: lessons from the Grameen experience. Long Range Planning, 43(2), 308-325.

\section{About the authors}

- Tiago José de Chaves, Professor in Business Administration, Master in Business AdministrationInternational Management from ESPM-São Paulo (2014). Areas of research: multinationals, marketing, social entrepreneurship, social impact, public administration.

E-mail: contatotchaves@gmail.com

- Thelma Valéria Rocha, Professor of International Marketing of PMDGl and MPCC at ESPM. PhD in Business Administration with emphasis in Marketing from FEA-USP. Master in Business Administration from EAESP / FGV with specialization in International Business from Stockholm School of Economics (SSE) Sweden. Research the International Marketing area, Franchise Internationalization and Relationship Marketing.E-mail: tvrocha@espm.br

- Jana Reuther, has a Master of International Management degree from CEMS FGV and University of Sydney.E-mail: jana.reuther@gmail.com

- Renata Fernandes Galhanone, Post-Doctoral fellow in International Marketing at PMDGI- ESPM. Post-Doctoral program in Consumer Behavior at FEI-SP Business School. PhD and Master degree in Business Administration from FEA-USP, Marketing track. Marketing specialization from ESPM - SP. Research focus on International Marketing, Franchise Internationalization, the Luxury Market, Strategic Marketing, and Consumer Behavior.E-mail: renatagalhanone@gmail.com 


\title{
Negócios sociais em corporações multinacionais: uma análise de práticas de marketing
}

\author{
Thiago José de Chaves ${ }^{A}$, Thelma Valéria Rocha ${ }^{B}$, \\ Jana Reuther ${ }^{C}$ and Renata Fernandes Galhanone ${ }^{B}$ \\ AFaculdade Católica de Santa Catarina - FACASC, Florianópolis, SC, Brasil \\ ${ }^{B}$ Escola Superior de Propaganda e Marketing - ESPM/SP, São Paulo, SP, Brasil \\ ${ }^{C}$ The University of Sidney, Sydney, Australia
}

\section{DETALHES DO ARTIGO}

\section{Histórico do artigo:}

Recebido 19 de Março de 2016

Aceito em 21 de Abril de 2017

Disponível online em 30 de Abril de 2017

Sistema de revisão "Double Blind Review"

Editor científico:

Ilan Avrichir

\section{Palavras-chaves:}

Negócios sociais

Empresas multinacionais

Estratégia de marketing

Mercados de baixa renda

\section{RESUMO}

O negócio social (NS) como uma categoria de organização que procura criar valor econômico e social de longo prazo para a maioria das pessoas tem atraído a atenção de decisores políticos, profissionais e estudiosos. Alguns autores destacam o papel que as corporações multinacionais têm na mitigação de problemas sociais e ambientais, oferecendo produtos e serviços para atender às demandas das populações de baixa renda. Com base em uma discussão sobre negócios sociais e iniciativas dentro das multinacionais, este artigo investiga como as subsidiárias brasileiras de duas grandes multinacionais (Coca-Cola e Danone) estão conduzindo NS em um país em desenvolvimento. Mais especificamente, nós nos concentramos em como eles estão usando seu know-how de marketing para alcançar os resultados desejados. Os casos foram escolhidos com base em sua relevância global e representatividade como empreendimentos NS. Nosso estudo mostra que essas iniciativas sociais estão ligadas às missões, valores e estratégias corporativas das empresas, e que visam a transformação social em relação ao seu core business. Nosso objetivo é contribuir tanto para a pesquisa acadêmica quanto para futuras iniciativas no Brasil e em outros países em desenvolvimento.

(C) 2017 Internext | ESPM. All rights reserved.

\section{To cite this article:}

Chaves, T. J., Rocha, T. V., Reuther, J., Galhanone, R. F. (2017). Social business in multinational corporations: an analysis of marketing practices. Internext - Revista Eletrônica de Negócios Internacionais, 12 (1), 62-75. DOI:10.18568/1980-4865.12176-90

To access this article: $h t t p: / / d x$. doi.org/10.18568/1980-4865.12176-90 